\title{
Postscript to: Why A. Smith Might Have Been Right, after All
}

\author{
Mario De Marchi \\ CNR-IRCRES, Consiglio Nazionale delle Ricerche-Istituto di Ricerca sulla Crescita Economica Sostenibile, Roma, Italy \\ Email: mario.demarchi@hotmail.com
}

How to cite this paper: De Marchi, M. (2020). Postscript to: Why A. Smith Might Have Been Right, after All. American Journal of Industrial and Business Management, 10, 1136-1138.

https://doi.org/10.4236/ajibm.2020.106075

Received: December 11, 2019

Accepted: June 14, 2020

Published: June 17, 2020

Copyright (c) 2020 by author(s) and Scientific Research Publishing Inc. This work is licensed under the Creative Commons Attribution-NonCommercial International License (CC BY-NC 4.0). http://creativecommons.org/licenses/by-nc/4.0/

\begin{abstract}
A suggestion is provided here for an attempt at making the Classical Approach to the study of prices and income distribution neutral with respect to ideological choices, a move which might perhaps promote progress in Political Economics.
\end{abstract}

\section{Keywords}

Methodology of Economics, Theory of Prices and Income Distribution

\section{An Incomplete Scientific Revolution}

The theoretical reconstruction of Classical Approach to Economics, started sixty years ago by Piero Sraffa, has been presented as a premise to the critique of the dominant Marginalism school (the would-be "Neo-Classical" perspective). Although the reasons for such a critique are well founded (in the inconsistencies of concerning capital measurement by the Marginalism), it has clashed against strong resistances by the Academic Elites, who seem to be motivated by the left-wing creed of Sraffa's followers rather than the validity of capital measurement methods used by Marginalism.

\section{Alternative Points of View within the Classical Perspective}

\subsection{The Surplus Approach...}

Since the publication of Production of Commodities by means of commodities (Sraffa, 1960), within the Classical theoretical approach the determination of income distribution might only have been interpreted as the result of an inverse nexus between wages and the rate of profit, described by equation:

$$
r=R(1-w)
$$


where " $r$ " is the rate of profit, " $w$ " is the wage, and " $R$ " is the maximum level (determined by technology) the rate of profit may reach in case of null wage. Sraffa's famous equation represents in a formal way the result of a clash between the classes of labourers and that of capitalists over the distribution of income, whose interpretation would inevitably have led towards the Marxian concept of "labour exploitation".

\section{2. ...or the Competition Approach?}

New perspectives, and a maybe welcome ideological freedom, appear to open up for the classical approach to economic analysis thanks to the results connected to Equation (B), initially put forth in (De Marchi, 2019). In it, whatever may be the net reproduction rate " $R$ " of the Standard Commodity (determined by technology), and the wage " $W$ ", in the end the rate of profit depends on prices' level " $V$ ", according to the relationship:

$$
(1+R) /(R-r)=V / w .
$$

So far, within Political Economics the main alternative has only been between Marginalism and Neo-Ricardian schools of thought. Now, scholars are presented with a way out. According to Equation (B), the determination of income distribution might be explained as the outcome of free choices and market mechanisms concerning the prices of commodities too, but this theoretical path could be followed without falling into the inconsistencies arising from capital measurement connected to Marginalism.

\section{Economics as a Normal Science}

Taking the level of prices as a determinant not determined circumstance of income distribution, was this analytical path undertaken, would put the study of competition (and its main driver, technological progress), at the centre of theoretical Economists' attention even more than it already is, due to the irrefutable, growing empirical evidence. Perhaps Economics would this way gain further realism and relevance.

If it were instead argued, like was once done by Sraffa, that the only reason why profits exist under capitalism is that workers cannot get the whole net product of the economic system (since they do not own the production means, Marx would have added), then one might counter that, in a capitalist economy workers, are able to get a part of surplus just because they fully possess their own labour-force, differently from what happens under the ancient, feudal and oriental modes of production. Presumably, some people may react deeming such assertion as immoral. This is just the core of the issue, and the cause for a crucial misunderstanding: in fact, Economics, as every other normal science, ought not to deal with "moral-immoral” assertions, only true-false, consistent-inconsistent ones.

\section{Conflicts of Interest}

The author declares no conflicts of interest regarding the publication of this paper. 


\section{References}

De Marchi, M. (2019). Why A. Smith Might Have Been Right, after All. American Journal of Industrial and Business Management, 9, 1980-1982.

https://doi.org/10.4236/ajibm.2019.911129

Sraffa, P. (1960). Production of Commodities by Means of Commodities. Cambridge: Cambridge University Press. 